\title{
Medical and scientific uses of human tissue
}

\author{
Onora O'Neill Newnham College, Cambridge University
}

When the Nuffield Council on Bioethics established its working party to look into ethical and legal issues surrounding the use of human tissue (1), we were initially much struck by the well known 1990 case of Moore $v$ Regents of the University of California. It was alleged that a valuable cell-line had been derived from Mr Moore's tissue without his knowledge and without his sharing in the financial benefits. Moore had sued his doctors and their employers, and although the case was ultimately settled out of court it seemed to raise many questions about use of human tissue in research and in clinical practice. However, we rapidly came to the view that the range of ethical, legal and social issues to do with human tissue was far wider than the Moore case suggested.

Those of us on the working party who were neither doctors nor scientists were impressed by the complex practices of tissue archiving (for example for routine pathological purposes) and storage (for example for blood transfusion) which had long been part of day-to-day medical practice. Those of us who were not lawyers were startled to find how patchy the legal regulation of most use of human tissue is in the United Kingdom. All of us became aware that medical and scientific research and practice are making ever more and more varied use of human tissue. We also realised that unscrupulous or unacceptable use of human tissue, even by a handful of researchers or doctors, might bring important medical and scientific activities into ill repute, and could lead to public demand for restrictions on less problematic uses of human tissue. The task was to try to distinguish appropriate use from abuse and to formulate workable guidelines that could be incorporated into actual medical and scientific practice, rather than to formulate proposals that would need new primary legislation, for which there is seldom time - or political will.

\section{Distinguishing proper use from abuse}

There is a high degree of consensus about some uses and abuses of human tissue: very few people will think cannibalism legitimate (unless in quite extraordinary circumstances); very many will think blood transfusion or the use of specimens from pathological archives for medical training and $N$ research legitimate. But there is also a great deal of confusion and disagreement about other cases.

We began by considering whether some of the standard ethical positions that have often been relied on in medical ethics might help in distinguishing abuse from proper use. Some time was spent considering whether either utilitarian or rights-oriented approaches could be useful in formulating guidelines for the use of human tissue.

Utilitarian approaches raised the usual problem that they combine a clear structure for making decisions with generally mushy data, so fail in the very areas where distinctions are most needed. We were also sensitive to the fact that because utilitarian reasoning permits, indeed requires, that we trade off happiness enjoyed in some lives against suffering borne in other lives, it may be insensitive to some of the issues that arise if tissue taken from one person is to be used for another's benefit.

A rights approach seemed to offer rather more, although there is much disagreement about which rights are likely to be relevant. The tough-minded sometimes propose that clarity could be achieved by regarding persons as owners of their tissue, and relying on normal procedures of 'informed' consent to regulate the appropriate sale and purchase of tissue; the less tough-minded invoke some less welldefined (or established) rights, such as rights to bodily autonomy or to bodily integrity.

A property rights approach to the use of human tissue leads to various problems. It flies in the face of the common law tradition: the courts have consistently refused to view living tissue as property; even cadavers may at most be 'lawfully possessed' rather than owned; only certain long-dead, or at least very dead, tissue (mummies, relics, some pathological specimens) has been treated by the courts as an object of commerce. Moreover, there are quite serious concerns both about the adequacy of ordinary commercial consent procedures to protect the more vulnerable should a market in human body parts be permitted, and about the broader unintended consequences of such a market (for example would commercial incentives put pressure on safety standards?). On the other hand, appeals to 
rights to 'bodily autonomy' or to 'bodily integrity', like the appeals to dignity and respect with which they are often associated, seemed too fuzzy to distinguish different sorts of cases.

\section{Injury: destruction, damage and degradation}

In the event the council decided that consent, while essential, is not enough to show that a use of human tissue is acceptable. It relied on two ethical tests: legitimate uses of human tissue must not inflict gratuitous injury, and must not override the consent of those whose tissues are used. Any use of human tissue that either injures gratuitously or removes tissue without consent is an abuse.

The first test, which has a long history in ethics, and in particular in medical ethics, does not forbid all injury. Medical practice itself commonly injures, but does so with therapeutic purpose. Like injury in self-defence, it is not gratuitous, but intended to limit injury. Uses of human tissue too may legitimately injure, we suggested, provided that the injury is not gratuitous, but rather judged necessary for therapeutic purposes. The legitimate therapeutic uses of human tissue may either be direct (for example transfusions, transplants) or indirect (for example medical education, basic and clinical research).

Other, abusive uses of human tissue are neither directly nor indirectly therapeutic (consider their use as food stuffs or as raw materials in industrial processes unconnected with therapy). Such gratuitous injury may either destroy, or damage or degrade human beings, or more narrowly their bodies and their tissues; it would generally be seen as failure to respect human beings or human dignity.

The concern not to permit uses of human tissue which gratuitously destroy or damage is relatively uncontroversial. The reason for rejecting uses which degrade is more complex. In any multi-cultural society there are differing views about what is degrading. For example, the funerary practices used by some religions are thought degrading ways of treating the human body by some outsiders; uses of the afterbirth sanctioned in some cultures would be seen as degrading in others. The illegitimacy of degrading uses of human tissue was stressed not because the council wished to deny cultural differences, but because it wished to allow them to be taken into account in context. It took the view that while there would be a high degree of agreement about uses of human tissue that destroy or damage, judgments about what degrades would quite properly vary with context.

\section{Removal of tissue and consent}

It is not enough to ensure that proposed uses of human tissue do not injure gratuitously. It is also important to be sure that tissue is never removed without due consent. As always in medical ethics, this well known proviso is more complex than appears on the surface. Tissues may be removed in the course of therapy; they may be removed when explicitly donated; they may be removed from cadavers. The appropriate ways of seeking consent from patients, donors and relatives must differ. Moreover, it is important not to lay exaggerated weight on some mythical notion of 'fully' informed consent, and to take account of the particular diffculties that arise in the case of those - children and others - who are not legally competent to consent.

In the case of removal of tissue from patients in the course of their treatment the council held that consent to treatment should constitute abandonment of tissue, and that the possibility that tissue might then be archived or stored and subsequently used in the treatment of the patient or others, or in medical research and education, should be indicated in general terms in standard consent procedures. An alternative would have been to use computer retrieval systems to re-contact patients to seek specific consent to each future use of a previously removed tissue. This approach was considered and rejected both because of the practical difficulties how is permission to be got from those who have moved house, or died? - and because the council was confident that full protection for patients, donors and relatives could be well, and perhaps better, achieved without a case-by-case consent procedure: nothing will be done to a patient whose abandoned tissue is later used for some appropriate purpose which would not have been done in any case. (Reproductive tissue is another matter, and in any case subject to separate regulation.) The case for commercial rewards for those whose tissue turns out to be rare and valuable was considered and rejected, largely because of a realization that much research uses many thousands of specimens, and that it is often a matter of chance that tissue from one rather than another source is used in a particular piece of research. Medical and scientific advances that depend on contributions from many thousands are not appropriately recognised by commercial rewards for a lucky few.

The protection of donors is quite another matter. By definition, donors give tissue that will not otherwise be removed from them. Here far more detailed information about intended uses of their tissue, and about risks of donation, must be provided, always with the proviso that any notion of 'fully informed' consent is mythical. Donation also raises particularly tricky questions in the case of children and of others not legally competent to consent. The council concluded that in these cases it was appropriate to have strong restrictions on taking tissue for any but therapeutic reasons, but thought that there should not be an absolute prohibition (consider the case of taking a blood sample from a healthy child for a family genetic study). By contrast, consent to removal of 
tissue from cadavers is relatively well regulated and there were few recommendations in this area.

\section{Research and new products}

One of the most rapidly expanding uses of human tissue is for research that may lead, for example, to the development of diagnostic tests and pharmaceuticals, which (unlike the tissue from which they originate) will become ordinary items of commerce (if of a very extraordinary sort), and will be marketed in the ordinary ways. It was necessary to consider how tissue whose removal is to be insulated from market forces could be made available to the biotechnology and pharmaceutical companies that may develop such products. The council concluded that a renewed and more formal emphasis on the procedures already in use in the United Kingdom could provide the appropriate barrier between industry on the one hand and patients, donors and relatives on the other. In the United Kingdom those who remove tissue - usually medical practitioners act in a non-commercial capacity and are responsible to professional bodies with exacting codes and standards. Their activity, and that of the hospital archives, of the transfusion services and of tissue banks can be seen as that of a medical intermediary. On the one hand they deal with patients, donors and relatives on a strictly non-commercial basis; on the other hand they make human tissue available not only to hospitals and university laboratories, but to companies who will undertake research that may lead to new products which they will market. It would be unacceptable for medical intermediaries to profit from the tissue they make available for research and development, but it would be acceptable for them to make charges to cover the costs of storage, quality control, administration, etc. The general principle is that medical intermediaries do not profit from their role, so will be able to maintain strictly professional standards in their relations with patients, donors and relatives. A corollary of this separation of roles is that the council recommended that the Department of Health maintain a register of approved tissue banks, so that commercial tissue banks would not be able to operate within the United Kingdom.

Commercial organisations, on the other hand, will quite legitimately seek profit, and in this area of research they will also have to take considerable financial risks. The fact that they would receive one crucial input for their research as a gift is not a method of guaranteeing them higher profits, but a method of preventing the penetration of commercial incentives into inappropriate areas of life.

Products that originate from research on human tissue also raise complex questions about patenting, with which patent officers are often ill-equipped to deal. The council recognised that inventions deriving from human tissue' are open to patenting, but also noted an urgent need for a further protocol to be added to the European Patent Convention, so that patent officers and national courts might refer to it in reaching judgments about ethically sensitive inventions deriving either from animal or from human tissue.

\section{Summary}

Inevitably a policy-oriented report on issues as complex and as rapidly changing as the medical and scientific uses of human tissue can achieve neither philosophical purity nor regulatory completeness. The council's strategy has been to begin with robust ethical principles, for which sound philosophical arguments can be given, which will (it is hoped) command widespread support. The council went on to argue for guidelines of sufficient, but not vapid, generality which could be of practical use to the various medical intermediaries, professional and regulatory bodies and research ethics committees which will carry out the tasks of detailed regulation and of making decisions that affect uses of human tissue. The council's hope is that the recommendations of the report can be absorbed into regulatory and professional practice, and where needed into government policy. If they can, the increasing diversity of uses of human tissue need lead neither to overt nor to covert 'commercialisation of the human body', but will also not put unnecessary restrictions on advances in research and medical practice.

Dr Onora O'Neill, CBE, FBA, is Principal, Newnham College, Cambridge University.

\section{References and notes}

(1) Nuffield Council on Bioethics. Human tissues: ethical and legal issues. London, 1995. (Copies obtainable from the Nuffield Council on Bioethics, 28 Bedford Square, London WC1B 3EG; tel: 0171-631-0566; price $£ 10.00$ inc $\mathrm{p}+\mathrm{p}$; cheques to the Nuffield Foundation.) 